Tug of war: adding and removing histone lysine methylation in Arabidopsis

Jun Xiao, Un-Sa Lee, Doris Wagner*

Department of Biology, University of Pennsylvania, Philadelphia, PA, 19104, USA

*Corresponding author: Doris Wagner (wagnerdo@sas.upenn.edu) 


\title{
Tug of war: adding and removing histone lysine methylation in Arabidopsis
}

\author{
Jun Xiao, Un-Sa Lee, Doris Wagner* \\ Department of Biology, University of Pennsylvania, Philadelphia, PA, 19104, USA \\ *Corresponding author: Doris Wagner (wagnerdo@sas.upenn.edu)
}

\begin{abstract}
Histone lysine methylation plays a fundamental role in the epigenetic regulation of gene expression in multicellular eukaryotes, including plants. It shapes plant developmental and growth programs as well as responses to the environment. The methylation status of certain amino-acids, in particular of the histone $3(\mathrm{H} 3)$ lysine tails, is dynamically controlled by opposite acting histone methyltransferase "writers" and histone demethylase "erasers". The methylation status is interpreted by a third set of proteins, the histone modification "readers", which specifically bind to a methylated amino-acid on the H3 tail. Histone methylation writers, readers and erasers themselves are regulated by intrinsic or extrinsic stimuli; this forms a feedback loop that contributes to development and environmental adaptation in Arabidopsis and other plants. Recent studies have expanded our knowledge regarding the biological roles and dynamic regulation of histone methylation. In this review, we will discuss recent advances in understanding the regulation and roles of histone methylation in plants and animals.
\end{abstract}

\section{Introduction:}

In eukaryotes, DNA is wrapped around the histone octamer (consisting of 2 copies of histones $\mathrm{H} 2 \mathrm{~A}, \mathrm{H} 2 \mathrm{~B}, \mathrm{H} 3$ and $\mathrm{H} 4$ ) to form a nucleosome, which serves as the building block of chromatin. In particular, the amino $(\mathrm{N})$-terminal tails of histones are subjected to multiple types of post-translation modifications, including methylation, acetylation, phosphorylation, ubiquitination. Histone modifications can change the histone - DNA interaction, for example by reducing the positive charge of histones (acetylation), or serve as signals (methylation, acetylation, ubiquitination) on chromatin. These signals can be recognized by other protein complexes such as chromatin regulators or the transcriptional machinery to further compact the chromatin or promote transcription $[1,2]$. In addition, the DNA itself can be covalently modified by methylation, this is required for genome integrity, heterochromatin formation at repetitive DNA and gene expression in concert with histone methylation [3]. 
Methylation is one of the best-studied histone modifications in metazoans and plants. Both lysine $(\mathrm{K})$ and arginine $(\mathrm{R})$ can be methylated to different extents, such as mono-, di-, tri-methylation on lysine or mono-, di-methylation (either symmetric or asymmetric) on arginine. Histone $\mathrm{H} 3$ in particular carries methyl marks on $\mathrm{K} 4, \mathrm{~K} 9, \mathrm{~K} 27$ and $\mathrm{K} 36$, which have been linked to transcriptional activation (H3K4, H3K36) or repression (H3K27, H3K9) [1,2]. In this review we will focus on $\mathrm{H} 3 \mathrm{~K} 4, \mathrm{~K} 27, \mathrm{~K} 36$ methylation, which are more prevalent in the generich euchromatic regions of the genome.

\section{Histone lysine methylation distribution and function}

The genome-wide enrichment and distribution of methylation at specific lysines on histone tails shows unique patterns consistent with their function in affecting gene expression, while at the same time transcription also impacts histone modification status; for example H3K36me3 can be deposited co-transcriptionally [4] (Figure 1). The presence of specific types of histone $\mathrm{H} 3$ lysine methylation in combination with other histone modifications, histone variants and DNA methylation make up the local chromatin landscape and define several predominant chromatin states with distinct biochemical properties and transcriptional potential $\left[5,6^{\star}\right]$.

H3K4me1 and H3K4me3 methylation in mammals are associated with enhancers and promoters, respectively [7]. When these marks co-occur at the same genomic location with the repressive modification $\mathrm{H} 3 \mathrm{~K} 27 \mathrm{me} 3$, the enhancers and promoters are inactive but poised for activation (bivalent) (for example, see [8*]). When H3K4me1 and H3K4me3 co-occur with H3K27 acetylation, enhancers or promoters are active [9] (Figure 1A). In plants, all three types of H3K4me (mono-, di-, tri-) are predominantly located on gene bodies, and more than two-thirds of the annotated genes are marked by at least one type of H3K4 methylation in a given tissue, developmental stage and environmental condition [10]. H3K4me2/3 accumulates predominantly at promoters and at the $5^{\prime}$ end of genic regions, whereas H3K4me1 is found over transcribed regions (Figure $1 \mathrm{~B})\left[5,6^{*}, 10\right]$. At the genome-wide level, H3K4me2 preferentially co-occurs with H3K27me3 [10]. True bivalent marked genomic regions - those where H3K4me2/3 and H3K27me3 cooccur on chromatin of the same fragment of genomic DNA as determined by sequential ChIP - have not yet been rigorously defined in plants (for review, see [9]). However, there is evidence for interplay between H3K4me2/3 and H3K27me3; for example, modulation of the H3K4me3/H3K27me3 in rice altered expression of genes involved in inflorescence meristem activity [11*]. Of note, $\mathrm{H} 3 \mathrm{~K} 4 \mathrm{me} 2 / 3$ is mutually exclusive with DNA methylation in Arabidopsis, while H3K4me1 is highly correlated with CG DNA methylation in the transcribed regions of genes [10]. In mammals, it was recently shown that $\mathrm{H} 3 \mathrm{~K} 4 \mathrm{me} 2 / 3$ demethylation is required for correct re-establishment of DNA methylation in 
oocytes [12]. Likewise, $\mathrm{H} 3 \mathrm{~K} 4 \mathrm{me} 3$ demethylation enables re-silencing of the epimutation caused by DNA hypomethylation in rice [13].

H3K4me3 in Arabidopsis is critical for a diverse array of developmental processes including control of developmental phase transitions and patterning $[14,15]$. Recently, H3K4me2/3 was linked to "memory" of environmental stresses such as drought or heat in plants $\left[16,17,18^{\star}\right]$. The H3K 4 me2/3 levels at the promoters of 'heat memory genes' are elevated after a first moderate stress treatment [18*]. The increased $\mathrm{H} 3 \mathrm{~K} 4 \mathrm{me} 2 / 3$ persists for 3 days and contributes to more dramatic transcriptional activation and increased stress tolerance upon a second stress treatment, perhaps caused by a requirement for hyper H3K4me3 for efficient transcription elongation $\left[17,18^{\star}\right]$.

In animals, H3K27me3 is frequently found in large domains covering multiple genes [19], while in plants H3K27me3 regions are generally restricted to the transcribed regions of single genes [6*] (Figure 1). In Arabidopsis, H3K27me1 is associated with heterochromatin while $\mathrm{H} 3 \mathrm{~K} 27 \mathrm{me} 2$ associates with both gene-rich euchromatin and repeat-rich heterochromatic regions [5,20]. Interestingly, allelespecific H3K27me3 marked regions were recently described in early endosperm in maize and Arabidopsis that contribute to paternally imprinted gene expression $\left[21^{*}, 22^{* \star}\right]$. In Drosophila, inter and intra-chromosomal interactions and topologically associated domains (TADs) can be reconfigured by environmental cues such as temperature stress, with new inter-TAD contacts forming between Polycomb marked promoters and enhancers [23]. Likewise, recent Arabidopsis $\mathrm{Hi}-\mathrm{C}$ data suggests that certain $\mathrm{H} 3 \mathrm{~K} 27$ me3-marked regions comprised of unusually large clusters of adjacent genes interact with each other at a relative short distance to form higher order chromatin structure $\left[24^{*}, 25^{* *}, 26\right]$.

In animals, during differentiation newly repressed genes gain H3K27me3 and derepression is primarily seen for Polycomb targets also marked by H3K4me3 in polycomb mutants $\left[27,28^{*}\right]$. Similarly, stress response genes were de-repressed in Arabidopsis polycomb mutants during dehydration only when marked with H3K4me3 [29]. In animals, evidence is emerging for a strong requirement for genic as opposed to intergenic H3K27me3 in repression of gene expression [30]. In plants, H3K27me3 is important for developmental stage transitions during seed germination, flowering, gametogenesis and fertilization (For review, see $[31,32])$. H3K27me3 is also important for imprinting and for epigenetic reprogramming between generations $\left[22^{* *}, 33^{* *}\right]$ (For review, see [34]). A key Polycomb target is the potent flowering repressor FLOWERING LOCUS C (FLC), which is silenced after prolonged cold (vernalization) by H3K27me3 histone methyltransferases of the Polycomb Repressive Complex 2 (PRC2) [35,36]. The 'memory of cold' is kept in 'cis', in the form of local H3K27me3 accumulation in the chromatin of the FLC gene, that can be inherited through cell division [37]. 
The silencing is reset by the histone demethylase ELF6 in the gametes by removing $\mathrm{H} 3 \mathrm{~K} 27 \mathrm{me} 3$; this ensures a requirement of vernalization in the next generation $\left[33^{* *}\right]$.

In animals, $\mathrm{H} 3 \mathrm{~K} 36 \mathrm{me} 2 / 3$ is primarily associated with actively transcribed genes and efficient transcription elongation [4,38] (Figure 1A). In agreement with this role, H3K36me3 primarily accumulates at the 3' end of the coding regions of actively transcribed genes [38]. Promotion of transcriptional elongation by H3K36me2/3 is executed in part by preventing intragenic transcription initiation together with repressive chromatin regulators, such as histone deacetylases (yeast) or $\mathrm{H} 3 \mathrm{~K} 4 \mathrm{me}$ demethylase/H3K9 methyltransferases and de novo DNA methyltransferases in humans [38,39]. In Arabidopsis, by contrast, H3K36me3 levels are highest in the 5'-half of actively transcribed genes. H3K36me2 levels, on the other hand, peak at the 3'-end of expressed genes and may be associated with the processivity of RNA Polymerase II [6] (Figure 1B). Whether the enrichment of $\mathrm{H} 3 \mathrm{~K} 36 \mathrm{me} 2$ in this region contributes for the prevention of intragenic transcription initiation, as in animals, has not yet been addressed.

Biological roles for H3K36me 3 in animals are to promote longevity and differentiation and to prevent tumorigenesis [40,41*]. In Arabidopsis, this histone modification has been linked to energy and nutrient homeostasis and contributes to the flowering response to prolonged cold $\left[42^{\star}, 43^{\star}\right]$. H3K36me3 but not $\mathrm{H} 3 \mathrm{~K} 4 \mathrm{me} 2 / 3$ opposes H3K27me3 at the FLC locus, suggesting these marks are mutually exclusive [43*]. Antagonism between H3K36me3 and H3K27me3 has also been described in animals [44].

\section{Adding and removing of histone modifications}

\section{Histone methyltransferases and their regulation}

Histone lysine methylation is catalyzed by histone lysine methyltransferases (HKMTs) of large family of SET Domain Group (SDG) proteins in plants and animals, named after three HKMTs found in Drosophila (Suppressor variegation 3-9, Enhancer of Zeste and Trithorax) [45].

\section{H3K4me writers}

In animals, writers of $\mathrm{H} 3 \mathrm{~K} 4 \mathrm{me}$ (mono-, di-, tri-) are the SET domain proteins MLL1-4 and SET1A, B (For review, see [46]). Unlike other histone methyltransferases, these proteins have little enzymatic activity on their own unless they are complexed with the WRAD subcomplex of COMPASS (comprised of WDR5, RbBP5, ASHL and DPY30 in yeast; COMPASS-like complex in mammals). It has recently been shown that this is because these 
enzymes lack an activating segment near the SET domain, which is instead provided by the RbBP5-ASHL heterodimer [ $\left.47^{* *}\right]$. In humans, transcription factors and transcriptional co-factors jointly recruit the DPY30-COMPASS histone modifiers to key regulators loci to balance the embryonic stem cell self-renewal with differentiation [48].

In Arabidopsis, there are 6 functionally defined H3K4me writers (Table 1). Several can add multiple methyl groups to H3K4 (SDG2 [49]; SDG25/ATXR7 [50]) or target different lysines (SDG26, H3K4me3 and H3K36me3 [51]; SDG4, $\mathrm{H} 3 \mathrm{~K} 4 \mathrm{me} 2 / 3$ and H3K36me3 [52]). Although ATX1 and ATX2 are highly similar to each other, ATX1 adds H3K4me3 whereas ATX2 writes H3K4me2 [53]. SDG2 mainly tri-methylates $\mathrm{H} 3 \mathrm{~K} 4$ [54].

The COMPASS-like complex is also highly conserved in Arabidopsis [14]. Whether COMPASS complex components are required for enzymatic activity of plant H3K4 methyltransferases remains to be addressed. Of note, loss-offunction of ASH2R, the Arabidopsis homolog of ASHL results in a significant decrease in the genome-wide H3K4me3 levels [14]. In Arabidopsis, the sequence-specific transcription factors bZIP28 and bZIP60 interact with COMPASS-like components both in vitro and in vivo, which likely facilitates the interaction between the COMPASS-like complex and histone methyltransferases [55*]. This suggests a mechanism for how the H3K4me2/3 writers are recruited to target loci. During heat stress, H3K4 methyltransferases may be recruited directly or indirectly by the transiently induced heats shock factor HSFA2 [18*].

\section{H3K27me writers}

In animals, PRC2 is able to mono-, di-, and trimethylate H3K27 in a spatially defined manner, contributing to different genomic functions [56] (For review, see $[4,57])$. Recent years have seen tremendous advances in our understanding of the regulation of PRC2 activity in animal systems. PRC2 activity is stimulated by the presence of $\mathrm{H} 3 \mathrm{~K} 27 \mathrm{me} 3$, by condensed chromatin and by the absence of the activating histone marks $\mathrm{H} 3 \mathrm{~K} 4 \mathrm{me} 3$ or $\mathrm{H} 3 \mathrm{~K} 36 \mathrm{me} 3$ [30,58,59]. PRC2 abundance

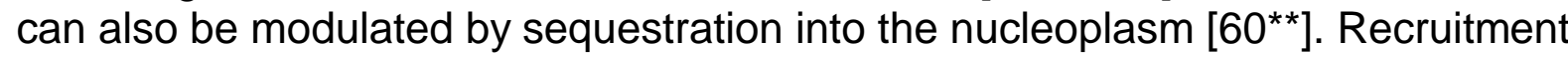
of PRC2 to genomic target loci is enabled by sequence specific binding proteins in Drosophila and - to a lesser extent - in mammals and by unmethylated CG rich promoter proximal DNA in mammals (reviewed in [61]). Histone modifications that anchor PRC2 include H3K27me3 and H2A monoubiquitination (H2Aub), the latter is generated by PRC1 (reviewed in [61]). In animals, RNAs, including noncoding RNAs, have been reported to recruit PRC2, yet definitive proof of such activity has remained difficult to obtain due to both technical and biological challenges (reviewed in [62]). More recent studies explain the promiscuity of the observed PRC2-RNA interactions. PRC2 associates 
nonspecifically with noncoding and coding nascent transcripts with high transcription rate coupled with an open chromatin environment inhibiting PRC2 activity. Interaction with nascent transcripts produced at lower levels in a more compacted chromatin environment, on the other hand, can help recruit PRC2 and promote its activity $[63,64]$.

In Arabidopsis, there are three SET domain containing proteins that act as catalytic subunits of PRC2: CURLY LEAF (CLF), SWINGER (SWN) or MEDEA (MEA); these enzymes mainly write H3K27me3 (For review, see [2]). On the basis of immunostaining, PRC2 may also contribute to H3K27me2 deposition in euchromatin, but the major writer of H3K27me2 remains unidentified [65]. ATXR5 and ATXR6, by contrast, are writers of H3K27me1 at heterochromatic regions during DNA replication in Arabidopsis (Table 1) [20]. PROLIFERATING CELL NUCLEAR ANTIGEN (PCNA) recruits ATXR5 and ATXR6 to the replication fork during $S$ phase [66]. Recent structural analyses showed that ATXR5 and ATXR6 specifically methylate the histone $\mathrm{H} 3$ variant $\mathrm{H} 3.1$ through a direct contact between the SET domain and alanine 31 of $\mathrm{H} 3.1\left[67^{\star}\right]$.

PRC2 has been implicated in developmental phase transitions, patterning, hormonal response and memory of environmental stimulus in Arabidopsis (For review, see $[31,32,68])$. PRC2 recruitment to target loci can be PRC1 independent or dependent, as in animals [69] (For review, see [70]). In the latter case, PRC1 complexes linked H2Aub deposition or other types of PRC1 complexes can recruit PRC2 [71,72]. Transcription factors also contribute to PRC2 recruitment in Arabidopsis [73,74**]. Recently, two classes of transcription factors were identified with prominent roles in PRC2 recruitment: the class I BASIC PENTACYSTEINE (BPC) transcription factor family, which binds GA repeat motifs and the C1-2iD Zinc finger transcription factors, which bind telobox motifs $\left[74^{* *}\right]$. Both motifs are enriched under PRC2 bound regions $\left[74^{* *}, 75,76\right]$ and may also recruit PRC1, albeit via different trans-factors $[77,78]$. The uncovered PRC2 recruitment mechanism, including a role for GA repeats motif and Zinc finger transcription factors as recruiters, is very similar to that in Drosophila [61,79]. In addition to transcription factors, DNA polymerase epsilon (ESD7) interacts with PRC2 and can recruit this complex to the flowering time loci $F T$ and SOC1 to maintain high H3K27me3 levels during mitosis [80].

Other factors may facilitate PRC binding and/or activity at target loci through creating a favorable local chromatin environment. The chromatin remodeler PKL [81] and DNA topoisomerase [82] may alter nucleosome occupancy or density to assist PRC2 binding or enzymatic activity. During vernalization, a cold induced specific PHD-PRC2 complex is formed that promotes enzymatic activity of PRC2 at the $F L C$ locus $[83,84]$. A recent study found that recruitment of a histone deacetylase and reduction in histone $\mathrm{H} 3$ acetylation is a prerequisite for 
enhanced PRC2 activity and perhaps occupancy at the $F L C$ locus during vernalization $\left[85^{\star *}\right]$. Finally, modulation of PRC2 complex composition can affect its function; a domesticated transposase (ALP1) antagonized Polycomb silencing through competition with accessory PRC2 complex components [86*]. Unlike in animals, only a few long non-coding RNAs (COLDAIR and APOLLO) were reported to associate with PRC complex components [87,88]. Overall, PRC2 activity and recruitment are highly regulated both in animals and plants.

\section{H3K36me writers}

Of the many writers for H3K36me in metazoans, only one - SETD2 - is implicated in H3K36me3 trimethylation. SETD2 physically interacts with the elongating (Ser-2 phosphorylated, Ser2P) form of RNA polymerase II [4,39] and is thus recruited co-transcriptionally. By contrast NSD1, 2, 3 do not interact with Pol II and are primarily responsible for mono- and dimethylation of H3K36 [39]. Additional H3K36 methyltransferases are not specific for this particular lysine and include ASH1, SETMAE and SMYD2 [4,38].

In plants, multiple SET domain containing proteins are responsible for writing H3K36me (Table 1). SDG8 and SDG4 catalyze the di- and tri-methylation of H3K36 [52,89]. SDG26 was reported to trigger H3K4me3, while SDG25 catalyzes H3K36me2 deposition in Arabidopsis $[51,90]$. Recently, ASHR3 was identified as a writer of H3K36me1 and H3K36me2 [91]. In rice, SDG724 and SDG725 mediate H3K36me2/3 deposition [92,93]. How these H3K36me2/3 writers are regulated and recruited to target loci in plants still needs to be elucidated. It is also not known whether any of the H3K36me writers are recruited co-transcriptionally (For review, see [2]). SDG8 was hypothesized to be recruited to $\mathrm{H} 3 \mathrm{~K} 4 \mathrm{me} 1 / 2$ via a conserved cysteine and tryptophan residue-containing (CW) domain [94]. However, a more recent study reports that H3K36me3 levels remain largely unaffected when H3K4me2 levels change [95]. Collectively, these H3K36 methyltransferases have been linked to nutrient and energy metabolism, touch responsive gene expression, cell division and flowering time $\left[47^{\star}, 51,95,96\right]$.

\section{Histone demethylases and their regulation}

In line with the dynamic transcription activity of genes during different developmental stages or under various environmental conditions, histone lysine methylation status is flexible (Figure 2). Histone turnover and dilution of parental modification marks during successive replication cycles enable passive removal of histone methylation [97] (For review, see [98]). Active removal of existing histone lysine methylation requires proteins with histone demethylase activity (Table 1). Two types of demethylases have been identified in plants: Lysine Specific Demethylase 1 (LSD1) homologues (4 members) and JmjC domain- 
containing proteins (21 members), which are further divided into subgroups with different substrate preferences (reviewed in [99]).

\section{Removal of H3K4me}

In animals, the flavin-adenine-dinucleotide dependent amino-oxidases LSD1 and LSD2/KDM1 demethylate H3K4me2 or me1, and the KDM5 subfamily of the $\mathrm{Fe}$ (II) 2- oxoglutarate-dependent oxygenases with JMJC domains demethylate H3K4me3, 2 and 1. The first PHD domain of KDM5A, B, D binds unmethylated $\mathrm{H} 3 \mathrm{~K} 4$, this stimulates demethylase activity, while the second PHD domain binds H3K4me3, providing a compelling model for the 'spread' of H3K4 demethylation $\left[100^{* *}\right]$. Interestingly, Drosophila KDM5 non-enzymatically activates gene expression via promoter H3K4me3 binding [101]. Jarid1a/KDM5A of the KDM5 subfamily can be recruited via PRC2 or the H3K9 methyltransferase G9a/KMT1C [102].

There are four homologues of LSD1 in Arabidopsis: FLD, LDL1, 2, 3. Several of these have been linked to flowering time control through regulation of $F L C$ expression by demethylase of H3K4me1/2 [103,104]. The Arabidopsis JmjC domain containing $\mathrm{H} 3 \mathrm{~K} 4$ me demethylases $\mathrm{JMJ} 14$, JMJ15, which can remove all types of H3K4me, and JMJ18, which removes H3K4me2/3 are involved in regulation of flowering time and in female gametophyte development [105-107]. In rice, JMJ703 can remove all types of methylation on H3K4 and alters the $\mathrm{H} 3 \mathrm{~K} 27 \mathrm{me} 3 / \mathrm{H} 3 \mathrm{~K} 4 \mathrm{me} 3$ ratio together with the H3K27me3 methyltransferase SDG711, a homologue of $E(z)\left[11^{*}, 108\right]$. Whether and how H3K4me3 demethylation spreads in plants is not yet known. Recruitment of H3K4me demethylases in Arabidopsis can be mediated by transcription factors. Two NAC type transcription factors NAC50 and NAC52 mediate targeting of JMJ14 to flowering time genes by directly binding to CTTGNNNNNCAAG consensus sequences $\left[109^{\star}, 110^{\star}\right]$.

\section{Removal of H3K27me}

Erasers of H3K27me3 and H3K27me2 in animals include the Ubiquitously transcribed Tetratricopeptide repeat $X$ chromosome protein (UTX or KDM6A) and the inducible expressed Jumonji D3 (JMJD3/KDM6B) demethylases. Loss of either enzyme activity causes only subtle gene expression changes. Both proteins also have non-enzymatic roles mediated by interaction with other chromatin regulators such as the SWI/SNF chromatin remodeler BRG1 (reviewed in [111]). A recent study shows that in T-cells both enzymes are redundantly required for removal of $\mathrm{H} 3 \mathrm{~K} 27 \mathrm{me} 3$ at a specific set of loci during differentiation [112]. KDM6A and KDM6B recruitment in animals is thought to occur via interaction with sequence specific binding proteins (reviewed in [111]). 
JHDM1D, by contrast, removes H3K27me2 and H3K27me1 (reviewed in [19]).

In Arabidopsis, ELF6 (JMJ11) [33**] and REF6 (JMJ12) [113] are two major erasers of H3K27me3 and H3K27me2; they are closely related JmjC paralogs and have different roles in the regulation of flowering time that may be related to their target gene preference [114]. ELF6 acts as a repressor in the flower promoting photoperiod pathway, whereas REF6 represses the flowering repressor $F L C\left[33^{* *}, 113,114\right]$. The subtle phenotypes of ref6 and elf6 mutants suggest the presence of additional, redundantly acting H3K27me3 demethylases. Indeed, two additional JmjC domain containing proteins, JMJ30 and JMJ32, jointly demethylate $\mathrm{H} 3 \mathrm{~K} 27 \mathrm{me} 3$ at the $F L C$ locus at elevated temperature to prevent premature flowering [115*]. In rice, JMJ705 has been described as a H3K27me2/3 demethylase. It removes H3K27me2/3 from pathogen defenserelated genes which increases their basal expression and their induction upon pathogen infection [116]. So far, the enzyme involved in removal of H3K27me1 is not known.

The Arabidopsis REF6 protein contains a tandem array of four $\mathrm{C} 2 \mathrm{H} 2$ Zinc finger domains at its $\mathrm{C}$-terminus, which was recently shown to be a sequence specific DNA binding domain that recognizes a CTCTGYTY motif $\left[117^{\star *}, 118^{\star}\right]$. REF6 binds to regions marked by H3K27me3 to counteract PcG mediated gene silencing during plant development [118*]. REF6 is also targeted to genomic loci by interaction with sequence specific binding factors. REF6 interacts with nuclear factor $Y(N F-Y)$, which recruits REF6 to the SOC1 promoter [119*]. In plants, histone demethylase activity can be modulated at the level of their RNA and protein accumulation. At elevated temperature the mRNA and protein of the JmjC domain containing histone demethylase $\mathrm{JMJ} 30$ are stabilized [115*]. Expression of the rice JMJ705, an H3K27me2/3 eraser, is induced by various stresses [116].

\section{Removal of H3K36me}

In animals, erasers of H3K36me include KDM4,8, KDM2A,2B and NO66 (reviewed in [19]) (Table 1). Consistent with the repression of the activity of the PRC2 complex by both H3K4me3 and H3K36me3, Polycomb repressive complexes recruit not only H3K4me3 demethylases (e.g. Jarid1a/KDM5A) but also H3K36me3 demethylases to active genes that need to be silenced [44]. For example, the PRC2-assocated PHF19 protein is a reader of H3K36me3 and recruits the H3K36me demethylase NO66 (Figure 2) [44]. Besides, KDM2A and $\mathrm{KDM} 2 \mathrm{~B}$, on the other hand, are recruited to target loci via a Zinc finger CxxC (ZF$\mathrm{CxxC}$ ) domain that preferentially recognizes nonmethylated $\mathrm{CpG}$ islands $[120,121]$.

In plants, it is unclear which demethylase specifically targets H3K36me3 and a 
directly link between PRC2 and H3K36me demethylation has not yet been established. JMJ30, a H3K27me2/3 demethylase [115*], is a clock component involved in controlling the circadian period [122] and flowering time [123*], by demethylation of $\mathrm{H} 3 \mathrm{~K} 36 \mathrm{me} 2$. An ambient temperature regulated MYB transcription factor, EFM, interacts with JMJ30 and recruits it to the $F T$ locus $\left[123^{\star}\right]$. The H3K36me2/3 demethylase activity of $\mathrm{JMJ} 30$, in vitro, is still under debate $\left[115^{\star}, 123^{\star}\right]$.

\section{Histone methylation readers}

Histone methylation marks are specifically recognized by "reader" proteins, which contact other protein complexes to interpret the epigenetic information and lead to specific molecular readouts (Figure 2). Domains that recognize histone lysine methylation include PHD (mainly K4), chromo (K4, K27, K36), WD40 (K4, K27), Tudor (K4), double/tandem Tudor (K4), MBT (K4) and PWWP (K36) domains (reviewed in [124]).

\section{H3K4me readers}

In animals, $\mathrm{H} 3 \mathrm{~K} 4 \mathrm{me}$ readers include PHD domain or Tudor domain containing proteins that are coupled to the transcriptional machinery (TAF3), histone acetylation (YNG1, Sgf29, ING4), histone deacetylation (ING1, ING2) and histone demethylation (PHF2, PHF8) (reviewed in [124,125]). Recently, several new readers of $\mathrm{H} 3 \mathrm{~K} 4 \mathrm{me}$ were identified. These include the PHD domain protein PHF13 which indirectly interacts with Ser5P Pol II and PRC2, potentially contributing to their recruitment to and stabilization at active and bivalent promoters, respectively [126*]. An intriguing reader is RACK7, which is a homolog of the H3K36me3 reader ZMYDN11/BS69. RACK7 binds to active enhancers and super enhancers and recruits the H3K4me demethylase KMD5C to prevent enhancer hyper-activation and over-accumulation of the associated genes [8]. Plant specific PHD domain containing Alphin1-like proteins (ALs) bind $\mathrm{H} 3 \mathrm{~K} 4 \mathrm{me} 3$ and interact with the PRC1 complex to silence seed maturation genes during germination, thus promoting a switch in histone methylation from H3K4me3 to H3K27me3 [72]. Another conserved set of PHD domain containing proteins, AtING1 and AtING2, are also able to bind H3K4m2/3 in vitro [127]. Recently, HDC1, a component of the Arabidopsis HDAC machinery, was reported to interact with AtING2, suggesting a similar link between H3K4me3 and histone deacetylation as in mammals [128*]. Likewise, two other PHD domain containing proteins, EBS and SHL, are able to recognize $\mathrm{H} 3 \mathrm{~K} 4 \mathrm{me} 2 / 3$, which likely contributes to the recruitment of these factors to target loci [129*]. EBS and $\mathrm{SHL}$ interact with the histone deacetylase HDA6 to maintain a low level of H3 acetylation at the loci of the flowering time genes FT and SOC1 [129*]. Notably, 
all plant PHD domain containing proteins mentioned above have been reported to be expressed ubiquitously throughout the plant.

\section{H3K27me readers}

In animals, the H3K27me3 readers are the PRC1 component $\mathrm{Pc}$ via its chromodomain and PRC2 component EED through the WD40 domain; other subunits stimulate the catalytic activity of the complex but are not directly involved in $\mathrm{H} 3 \mathrm{~K} 27 \mathrm{me} 3$ recognition, as reported by a recent structural study of an active PRC2 complex [130]. Another chromodomain containing PRC1 component, CBX7, can read H3K27me2 [131]. Readers of H3K27me2/3 reinforce the repressive chromatin status. This may be achieved in part through modulating chromatin topology $[132,133]$. Similar findings were reported in Arabidopsis [134].

In plants, the FIE PRC2 complex component binds H3K27me3 to reinforce enrichment of H3K27me3 at target loci [135], like its counterpart EED in animals. The plant PRC1 component LHP1 also binds H3K27me3 via its chromodomain to further silence gene expression [136,137]. Interestingly, while LHP1 binding profile is highly overlapping with the H3K27me3 mark, the Ihp1 null mutant of this single copy gene has relatively mild phenotypic defects. Recently, genetic screens identified two TRB proteins as Ihp1 mutant enhancer. Their binding overlaps with telobox-motif enriched H3K27me3 marked genomic regions and both the TRBs and LHP1 silence target genes [77].

\section{H3K36me readers}

MRG15 family proteins are components of the NuA4 histone acetyltransferase complex in both Arabidopsis and animals, and function as readers of $\mathrm{H} 3 \mathrm{~K} 36 \mathrm{me} 3$ via their chromodomains $[38,138]$. Other H3K36me 3 readers in animals contain PWWP domains (like that in the de novo DNA methylase DNMT3a or the H3K36me3 histone methyltransferases NSD1, 2, 3) (reviewed in [38]). Tudor domains can also read H3K36me3, for example that of the Polycomb associated PHF19 protein, which recruits the NO66 H3K36 demethylase [44]. Another H3K36me3 reader, ZMYND11, serves to dampen Pol II elongation and is linked to splicing $\left[41^{*}, 139\right]$.

In Arabidopsis, two MRG15 family protein homologs, MRG1 and MRG2, localize to euchromatin and recognize the H3K36me3 mark. Both proteins are ubiquitously expressed [140*]. MRG1 and MRG2 redundantly impact expression of the flowering time genes FLC and FT through bridging H3K36me3 and $\mathrm{H} 4$ acetylation to achieve high expression levels [141**]. In addition, MRG1 and MRG2 physically interact with the histone methyltransferases HAM1 and HAM2, 
two homologs of the catalytic subunit of the yeast NuA4 complex, Esa1 [141**]. MRG1 and MRG2 have been also shown to bind H3K4me3 in vitro, which has been further confirmed by solving the structure of a co-crystal [140*]. Another possible mechanism for MRG2 recruitment is via its physical interaction with CONSTANS (CO); the two proteins enhance each other's binding to the FT locus and jointly activate it [140*]. In rice, MRG702, a homolog of Arabidopsis MRG1,2, is also ubiquitously expressed and can read the H3K36me2/3 mark in the brassinolide hormone response pathway as well as during the flowering transition [142].

\section{Closing remarks and future perspectives}

Developmental transitions occur throughout the entire lifecycle of plants until senescence. Likewise, plants as sessile organisms need to continuously respond to a changing environment. A large number of genes are being turned on and shut off in response to intrinsic and extrinsic stimuli. Dynamic genome-wide and gene locus specific alteration in histone methylation contribute to the orchestration of these responses. Changes in the accumulation, recruitment or activity of histone methylation writers, readers or erasers can provide global yet precise modulation of histone modification to tune plant development and stress responses. Recent studies have enhanced our understanding about histone methyltransferases, demethylases and histone methylation readers, yet many open questions remain.

For example, how methyltransferase and demethylase activity is modulated in response to endogenous cues (e.g. hormone concentration, nutrition condition) or environmental stimuli (e.g. light, temperature, water) will be of great interest to explore further. Recruitment to target loci, change in mRNA or protein level abundance, enzymatic activity, complex composition of each writer or eraser help determine the final methylation status.

In addition, readers of the histone methylation are generally understudied. How different reader proteins collectively interpret the histone methylation status in combination with other chromatin marks to either solidify or overturn its effect on gene expression, genome accessibility or chromatin topology and thus shape plant development and response to stress remains to be elucidated. In this capacity, readers not only cross talk with writers and erasers, but are themselves subject to regulation in response to intrinsic and extrinsic cues.

\section{Acknowledgement}

We gratefully acknowledge funding from National Science Foundation (NSF MCB-1614355 and MCB-1243757) to D.W. 
Table 1. Writers, erasers and readers of histone methylation (H3K4, K27, K36) in plantsos and animals.

\begin{tabular}{|c|c|c|c|c|c|c|c|}
\hline \multirow{2}{*}{\multicolumn{2}{|c|}{ Histone marks }} & \multicolumn{2}{|c|}{ Writers } & \multicolumn{2}{|c|}{ Erasers } & \multicolumn{2}{|c|}{ Readers } \\
\hline & & Plants & Animals & Plants & Animals & Plants & Animals \\
\hline \multirow{3}{*}{ H3K4 } & H3K4me1 & SDG25/ATXR7 [50] & $\begin{array}{l}\text { MLL1-4, } \\
\text { SET1A,B } \\
{[46]}\end{array}$ & $\begin{array}{c}\text { FLD, LDL1/2 } \\
\text { [103,104], } \\
\text { JMJ14 [105], } \\
\text { JMJ15 [106]; } \\
\text { JMJ703\# [108]. }\end{array}$ & $\begin{array}{c}\text { LSD1, LSD2 } \\
\text { [19] }\end{array}$ & - & - \\
\hline & H3K4me2 & $\begin{array}{l}\text { ATX2 [53], SDG2 } \\
\text { [49], SDG4 [52], } \\
\text { SDG25/ATXR7 [50] }\end{array}$ & $\begin{array}{l}\text { MLL1-4, } \\
\text { SET1A,B } \\
\text { [46] }\end{array}$ & $\begin{array}{c}\text { FLD, LDL1/2 } \\
\text { [103,104], } \\
\text { JMJ14 [105], } \\
\text { JMJ15 [106], } \\
\text { JMJ18 [107]; } \\
\text { JMJ703\# [108]. }\end{array}$ & $\begin{array}{c}\text { LSD1, LSD2, NO66, } \\
\text { KDM5A,B,C,D } \\
{[19]}\end{array}$ & $\begin{array}{c}\text { AtING1,2 } \\
\text { [127], EBS, } \\
\text { SHL (PHD) } \\
{\left[129^{\star}\right]}\end{array}$ & $\begin{array}{c}\text { (Chromo); ING2, } \\
\text { ING4, TAF3, } \\
\text { PHF2, PHF8, } \\
\text { PHF13 (PHD); } \\
\text { JMJD2A,C, } \\
\text { Sgf29 (Tudor); } \\
\text { RACK7 } \\
\text { [124] }\end{array}$ \\
\hline & H3K4me3 & $\begin{array}{c}\text { ATX1 [57], SDG2 } \\
\text { [49], SDG4 [52], } \\
\text { SDG25/ATXR7 [50], } \\
\text { SDG26 [51] }\end{array}$ & $\begin{array}{l}\text { MLL1-4, } \\
\text { SET1A,B } \\
{[46]}\end{array}$ & $\begin{array}{c}\text { JMJ14 [105], } \\
\text { JMJ15 [106], } \\
\text { JMJ18 [107]; } \\
\text { JMJ703\# [108]. }\end{array}$ & $\begin{array}{c}\text { NO66, KDM2B, } \\
\text { KDM5A,B,C,D } \\
{[19]}\end{array}$ & $\begin{array}{c}\text { ALs [/2], } \\
\text { AtING1,2 } \\
\text { [127], EBS, } \\
\text { SHL (PHD) } \\
\text { [129*]; } \\
\text { WDR5a } \\
\text { (WD40) [14] }\end{array}$ & - \\
\hline \multirow{3}{*}{ H3K27 } & H3K27me1 & $\begin{array}{c}\text { ATXR5, ATXR6 } \\
{[20]}\end{array}$ & $\begin{array}{c}\mathrm{EZH} 1,2 \\
{[56]}\end{array}$ & - & $\begin{array}{l}\text { JHDM1D } \\
{[19]}\end{array}$ & - & - \\
\hline & H3K27me2 & $\begin{array}{c}\text { CLF/SDG1, } \\
\text { SWN/SDG10, } \\
\text { MEA/SDG5 } \\
\text { [2] }\end{array}$ & $\begin{array}{c}\mathrm{EZH} 1,2 \\
{[56]}\end{array}$ & $\begin{array}{c}\text { JMJ11/ELF6 } \\
{\left[33^{\star \star}\right],} \\
\text { JMJ12/REF6 } \\
{[113],} \\
\text { JMJ30, JMJ32 } \\
{\left[115^{\star}\right] ;} \\
\text { JMJ705\# [116]. }\end{array}$ & $\begin{array}{c}\text { JHDM1D, KDM6A,B } \\
\text { [19] }\end{array}$ & - & $\begin{array}{c}\text { Pc, CDY, } \\
\text { CDYL2,3, } \\
\text { CBX7, MPP8 } \\
\text { (chromo) } \\
\text { [124] }\end{array}$ \\
\hline & H3K27me3 & $\begin{array}{c}\text { CLF/SDG1, } \\
\text { SWN/SDG10, } \\
\text { MEA/SDG5 } \\
{[2]}\end{array}$ & $\begin{array}{c}\mathrm{EZH} 1,2 \\
{[56]}\end{array}$ & $\begin{array}{c}\text { JMJ11/ELF6 } \\
{\left[33^{* *}\right],} \\
\text { JMJ12/REF6 } \\
{[113],} \\
\text { JMJ30, JMJ32 } \\
{\left[115^{\star}\right] ;} \\
\text { JMJ705\# [116]. }\end{array}$ & $\begin{array}{c}\text { KDM6A,B } \\
{[19]}\end{array}$ & $\begin{array}{c}\text { LHP1 } \\
{[136,137],} \\
\text { FIE [135] }\end{array}$ & $\begin{array}{l}\text { EED, LRWD1 } \\
\text { (WD40) } \\
{[124]}\end{array}$ \\
\hline \multirow{3}{*}{ H3K36 } & H3K36me1 & ASHR3 [91] & $\begin{array}{c}\text { NSD1-3, } \\
\text { SMYD2, ASH1, } \\
\text { SETMAE } \\
{[38]}\end{array}$ & - & $\begin{array}{l}\mathrm{KDM} 2 \mathrm{~A}, \mathrm{~B} \\
{[19]}\end{array}$ & - & - \\
\hline & H3K36me2 & $\begin{array}{l}\text { SDG25 [90], SDG8 } \\
\text { [89], ASHR3 [91]; } \\
\text { SDG724\# [92], } \\
\text { SDG725\# [93]. }\end{array}$ & $\begin{array}{c}\text { NSD1-3, } \\
\text { SMYD2, ASH1, } \\
\text { SETMAE } \\
{[38]}\end{array}$ & $\begin{array}{l}\text { JMJ30 } \\
{\left[123^{*}\right]}\end{array}$ & $\begin{array}{c}\text { NO66, KDM8, } \\
\text { KDM2A,B, } \\
\text { JHDM3A,B,C,D } \\
{[19]}\end{array}$ & $\begin{array}{l}\text { MRG702\# } \\
\text { [142] }\end{array}$ & - \\
\hline & H3K36me3 & $\begin{array}{l}\text { SDG4 [52], SDG8 } \\
\text { [89], SDG26 [51]; } \\
\text { SDG724\# [92], } \\
\text { SDG725\# [93]. }\end{array}$ & $\begin{array}{l}\text { SET2D } \\
{[38]}\end{array}$ & $\begin{array}{l}\text { JMJ30 } \\
{\left[123^{*}\right]}\end{array}$ & $\begin{array}{c}\text { NO66, } \\
\text { JHDM3A,B,C,D } \\
{[19]}\end{array}$ & $\begin{array}{c}\text { MRG1,2 } \\
\text { (Chromo) } \\
{\left[140^{\star}, 141^{\star *}\right] ;} \\
\text { MRG702\# } \\
{[142]}\end{array}$ & $\begin{array}{c}\text { EAF3, MRG15 } \\
\text { (Chromo); } \\
\text { DNMT3A, } \\
\text { NSD123, } \\
\text { ZMYND11 } \\
\text { (PWWP); } \\
\text { PHF19 (Tudor) } \\
\text { [124] }\end{array}$ \\
\hline
\end{tabular}

- : writer, eraser or reader unknown. \#: protein from rice. 


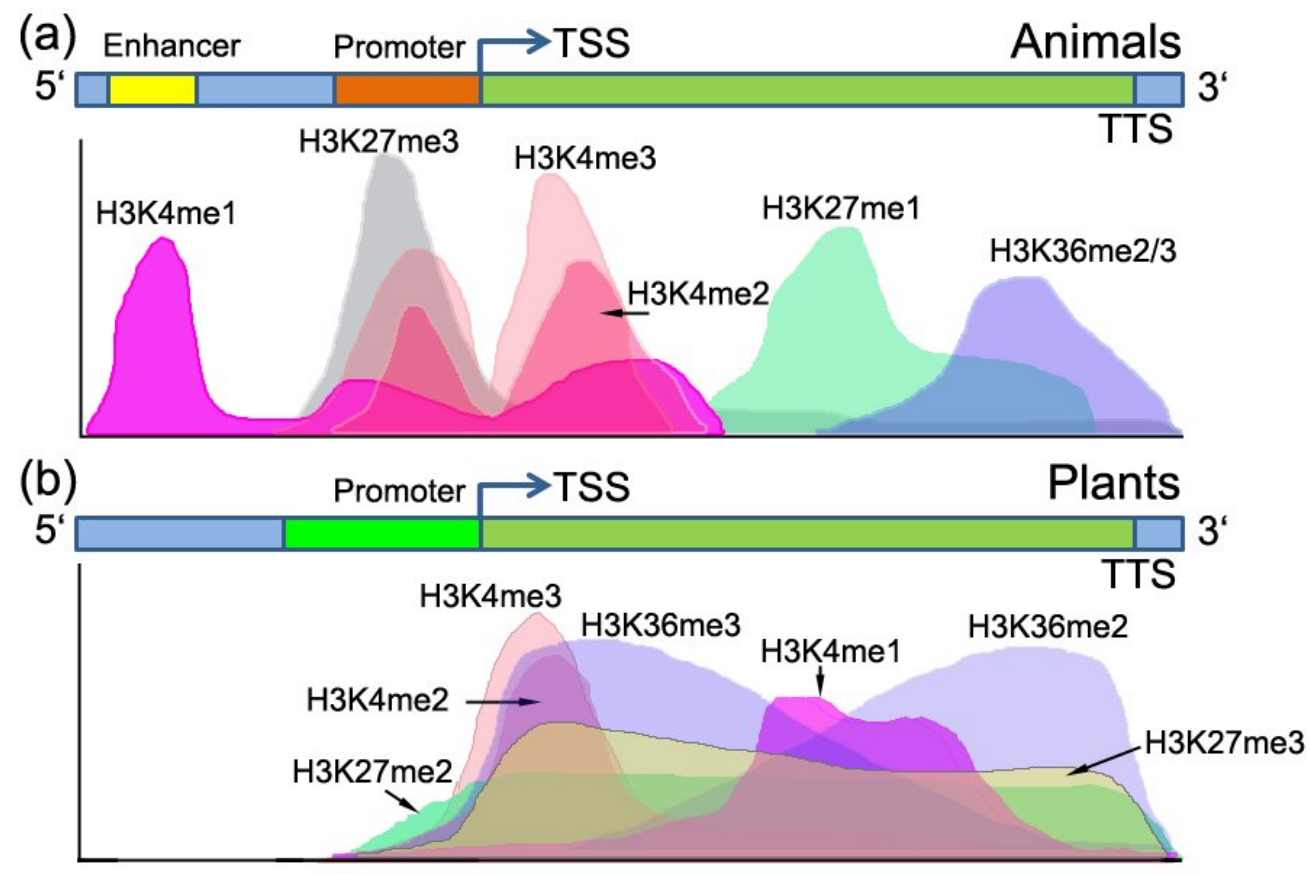

Figure 1. Histone lysine methylation distribution in animals and plants

The distribution of histone lysine methylation in animals (modified from [19]) and plants along transcription units (summarized based on $[5,6,10]$ ). (a) In animals, H3K4me1 levels are high at enhancers and lower at the promoter or the 5' end of the transcription unit, while $\mathrm{H} 3 \mathrm{~K} 4 \mathrm{me} 2 / 3$ is high at promoters or around the TSS regions of active or poised genes. H3K27me2/3 is highly enriched at the promoter of inactive or poised genes, while H3K27me1 is found in center of the transcription unit. $\mathrm{H} 3 \mathrm{~K} 36 \mathrm{me} / 3$ is enriched towards the 3 ' end of the gene body. (b) In plants, H3K4me2/3 is enriched at the proximal promoter and TSS site, while H3K4me1is found over the transcribed region. H3K27me2/3 is enriched throughout the gene body, with slightly higher abundance of H3K27me3 near the TSS. In contrast to animals, H3K36me3 occupies gene body towards the 5' end while H3K36me2 is more enriched towards the 3' end of transcribed genes. Note: the data presented here covers both active and inactive genes and the relative abundance among different types of histone methylation is not in real scale. Profiles shown correspond to an average view, especially in plants where the data were usually generated from whole seedlings. Finally, the operational definition of 'promoter' differs in animals and plants. In animals, promoter denotes the binding region for the general transcriptional machinery, about 100 bp upstream of the TSS. In Arabidopsis promoter denotes the upstream intergenic region (1-2 kb or more) and contains the core promoter as well as enhancers. TSS: transcription start site; TTS: transcription termination site. 


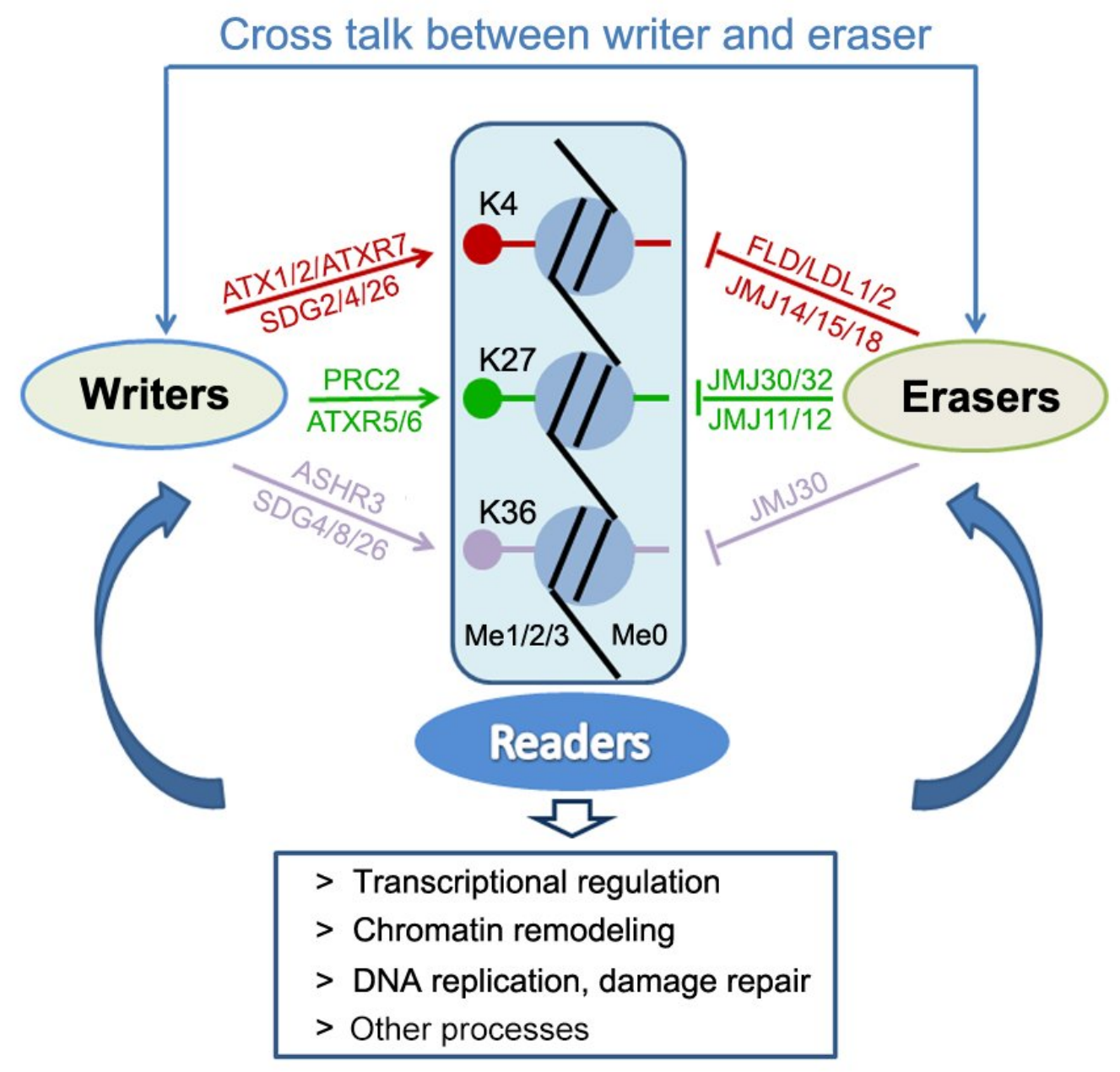

Figure 2. Histone methylation writers, readers and erasers in Arabidopsis

Histone lysine methylation is a dynamic process. Various histone methylation writers (histone lysine methyltransferases) and erasers (histone demethylases) place or remove histone methylation marks at different lysine residues of $\mathrm{H} 3$ (K4, $\mathrm{K} 27, \mathrm{~K} 36$ ) and frequently are specific as to the number of methyl groups they attach or remove (mono-, di-, or tri methyl). These enzymes act in complexes that modulate their activity and are generally targeted by recruiters to the correct genomic location. Histone methylation readers (proteins with different histone mark recognition domains, such as PHD, chromo, Tudor and PWWP) bind and interpret the histone methylation signals to alter transcription, DNA replication, chromatin structure and nuclear architecture. Furthermore, cross talk among writers, erasers and readers fine-tunes the readout of the histone methylation, which together with other features of the chromatin landscape helps shape 
organism development and survival in a changing environment. 


\section{References and recommended reading}

Papers of particular interest, published within the period of review, have been highlighted as:

* of special interest

${ }^{* *}$ of outstanding interest

1. Bannister AJ, Kouzarides T: Regulation of chromatin by histone modifications. Cell Res. 2011, 21:381-395.

2. Liu C, Lu F, Cui X, Cao X: Histone methylation in higher plants. Annu. Rev. Plant Biol. 2010, 61:395-420.

3. Smith ZD, Meissner A: DNA methylation: roles in mammalian development. Nat. Rev. Genet. 2013, 14:204-20.

4. Zhang $\mathrm{T}$, Cooper S, Brockdorff $\mathrm{N}$ : The interplay of histone modifications - writers that read. EMBO Rep 2015, 16:1467-1481.

5. Roudier F, Ahmed I, Bérard C, Sarazin A, Mary-Huard T, Cortijo S, Bouyer D, Caillieux E, Duvernois-Berthet E, Al-Shikhley L, et al.: Integrative epigenomic mapping defines four main chromatin states in Arabidopsis. EMBO J. 2011, 30:1928-1938.

6. Sequeira-Mendes J, Aragüez I, Peiró R, Mendez-Giraldez R, Zhang X, Jacobsen SE, Bastolla U, Gutierrez C: The Functional Topography of the Arabidopsis Genome Is Organized in a Reduced Number of Linear Motifs of Chromatin States. Plant Cell 2014, 26:2351-2366.

* The authors define nine predominant chromatin states with distinct biochemical properties and transcriptional potential based on a comprehensive study of genome wide histone modification, histone variants, DNA methylation and DNA sequence.

7. Cheng J, Blum R, Bowman C, Hu D, Shilatifard A, Shen S, Dynlacht BD: A role for $\mathrm{H} 3 \mathrm{~K} 4$ monomethylation in gene repression and partitioning of chromatin readers. Mol. Cell 2014, 53:979-992.

8. Shen H, Xu W, Guo R, Rong B, Gu L, Wang Z, He C, Zheng L, Hu X, Hu Z, et al.: Suppression of Enhancer Overactivation by a RACK7-Histone Demethylase Complex. Cell 2016, 165:331-342.

* The authors identify the H3K4me3 "reader" RACK7, which binds to active enhancers and super enhancers and recruits the H3K4me demethylase 
KMD5C to prevent enhancer overactivation and tumorgenesis.

9. Voigt $\mathrm{P}$, Tee WW, Reinberg D: A double take on bivalent promoters. Genes Dev. 2013, 27:1318-1338.

10. Zhang X, Bernatavichute $Y$ V, Cokus S, Pellegrini M, Jacobsen SE:

Genome-wide analysis of mono-, di- and trimethylation of histone H3 lysine 4 in Arabidopsis thaliana. Genome Biol. 2009, 10:R62.

11. Liu X, Zhou S, Wang W, Ye Y, Zhao Y, Xu Q, Zhou C, Tan F, Cheng S, Zhou DX: Regulation of histone methylation and reprogramming of gene expression in the rice inflorescence meristem. Plant Cell 2015, 27:1428-44.

* Altering the $\mathrm{H} 3 \mathrm{~K} 4 \mathrm{me} 3$ and $\mathrm{H} 3 \mathrm{~K} 27 \mathrm{me} 3$ ratio by regulation of specific histone methyltrasferase and histone demethylase affects inflorescence meristem development in rice.

12. Stewart KR, Veselovska L, Kim J, Huang J, Saadeh H, Tomizawa SI, Smallwood SA, Chen T, Kelsey G: Dynamic changes in histone modifications precede de novo DNA methylation in oocytes. Genes Dev. 2015, 29:2449-2462.

13. Chen X, Liu X, Zhao Y, Zhou DX: Histone H3K4me3 and H3K27me3 regulatory genes control stable transmission of an epimutation in rice. Sci. Rep. 2015, 5:13251.

14. Jiang D, Kong NC, Gu X, Li Z, He Y: Arabidopsis COMPASS-like complexes mediate histone $\mathrm{H} 3$ lysine-4 trimethylation to control floral transition and plant development. PLoS Genet. 2011, 7:e1001330.

15. Yao X, Feng H, Yu Y, Dong A, Shen WH: SDG2-Mediated H3K4 Methylation Is Required for Proper Arabidopsis Root Growth and Development. PLoS One 2013, 8:e56537.

16. Ding Y, Fromm M, Avramova Z: Multiple exposures to drought "train" transcriptional responses in Arabidopsis. Nat. Commun. 2012, 3:740.

17. Ding Y, Ndamukong I, Xu Z, Lapko H, Fromm M, Avramova Z: ATX1Generated H3K4me3 Is Required for Efficient Elongation of Transcription, Not Initiation, at ATX1-Regulated Genes. PLOS Genet. 2012, 8:e1003111.

18. Lämke J, Brzezinka K, Altmann S, Bäurle I: A hit-and-run heat shock factor governs sustained histone methylation and transcriptional 
stress memory. EMBO J. 2016, 35:162-75.

* In this study, the authors find H3K4me2/3 is implicated in heat stress "memory", in which H3K4me writer is recruited to the target loci indirectly by a transient heat induced factor HSFA2.

19. Kooistra SM, Helin K: Molecular mechanisms and potential functions of histone demethylases. Nat Rev Mol Cell Biol 2012, 13:297-311.

20. Jacob Y, Stroud H, Leblanc C, Feng S, Zhuo L, Caro E, Hassel C, Gutierrez C, Michaels SD, Jacobsen SE: Regulation of heterochromatic DNA replication by histone $\mathrm{H} 3$ lysine 27 methyltransferases. Nature 2010, 466:987-991.

21. Zhang M, Xie S, Dong X, Zhao X, Zeng B, Chen J, Li H, Yang W, Zhao H, Wang $G$, et al.: Genome-wide high resolution parental-specific DNA and histone methylation maps uncover patterns of imprinting regulation in maize. Genome Res. 2014, 24:167-176.

* The authors identify genome wide allele-specific DNA methylation and H3K27me3 in maize endosperm and find a correlation between paternal allele-specific gene expression and maternal allele-specific H3K27me3 and DNA demethylation.

22. Moreno-Romero J, Jiang H, Santos-Gonzalez J, Köhler C: Parental epigenetic asymmetry of PRC2-mediated histone modifications in the Arabidopsis endosperm. EMBO J. 2016, 1:1-14.

** Allele-specific H3K27me3 marked regions were described in early endosperm in Arabidopsis that contribute to paternally imprinted gene expression, while Polycomb mediated H3K27me3 deposition contributes to the DME-mediated hypomethylation of the maternal genome after fertilization.

23. Li L, Lyu X, Hou C, Takenaka N, Nguyen HQ, Ong CT, Cubeñas-Potts C, Hu M, Lei EP, Bosco G, et al.: Widespread Rearrangement of 3D Chromatin Organization Underlies Polycomb-Mediated Stress-Induced Silencing. Mol. Cell 2015, 58:216-231.

24. Feng S, Cokus S, Schubert V, Zhai J, Pellegrini M, Jacobsen S: Genomewide Hi-C Analyses in Wild-Type and Mutants Reveal High-Resolution Chromatin Interactions in Arabidopsis. Mol. Cell 2014, 55:694-707.

* Hi-C analysis suggests the Arabidopsis genome contains relatively small interactive regions scattered throughout the genome covered by 
H3K27me3 and H3K9me2.

25. Liu C, Wang C, Wang G, Becker C, Zaidem M, Weigel D: Genome-wide analysis of chromatin packing in Arabidopsis thaliana at single-gene resolution. Genome Res. 2016, doi:10.1101/gr.204032.116.

** In this study, the authors perform $\mathrm{Hi}-\mathrm{C}$ analysis with gene-level resolution and find H3K27me3 is over-represented at the promoter regions of genes that form long distance contacts, while local, gene body chromatin loops preferentially occur in highly expressed genes.

26. Grob S, Schmid M, Grossniklaus U: Hi-C Analysis in Arabidopsis Identifies the KNOT, a Structure with Similarities to the flamenco Locus of Drosophila. Mol. Cell 2014, 55:678-693.

27. Wassef M, Rodilla V, Teissandier A, Zeitouni B, Gruel N, Sadacca B, Irondelle M, Charruel M, Ducos B, Michaud A, et al.: Impaired PRC2 activity promotes transcriptional instability and favors breast tumorigenesis. Genes Dev. 2015, 29:2547-2562.

28. Jadhav U, Nalapareddy K, Saxena M, O'Neill NK, Pinello L, Yuan GC, Orkin SH, Shivdasani RA: Acquired Tissue-Specific Promoter Bivalency Is a Basis for PRC2 Necessity in Adult Cells. Cell 2016, doi:10.1016/j.cell.2016.04.031.

* In this study, Polycomb targets are found to fall into multiple categories with different de-repression activity based on co-occurrence of H3K4me2/3 and H3K27me3 bivalent histone marks.

29. Liu N, Fromm M, Avramova Z: H3K27me3 and H3K4me3 chromatin environment at super-induced dehydration stress memory genes of arabidopsis thaliana. Mol. Plant 2014, 7:502-513.

30. Lu C, Jain SU, Hoelper D, Bechet D, Molden RC, Ran L, Murphy D, Venneti S, Hameed M, Pawel BR, et al.: Histone H3K36 mutations promote sarcomagenesis through altered histone methylation landscape. Science 2016, 352:844-9.

31. Xiao J, Wagner D: Polycomb repression in the regulation of growth and development in Arabidopsis. Curr. Opin. Plant Biol. 2015, 23:15-24.

32. Mozgova I, Köhler C, Hennig L: Keeping the gate closed: Functions of the polycomb repressive complex PRC2 in development. Plant J. 2015, 83:121-132. 
33. Crevillen P, Yang H, Cui X, Greeff C, Trick M, Qiu Q, Cao X, Dean C: Epigenetic reprogramming that prevents transgenerational inheritance of the vernalized state. Nature 2014, 515:587-590.

** ELF6, a H3K27me3 demethylase, is needed for resetting flowering repressor FLC expression by removing H3K27me3 during gametogenesis to ensure a vernalization requirement in the next generation.

34. Gehring M: Genomic imprinting: insights from plants. Annu. Rev. Genet. 2013, 47:187-208.

35. Michaels SD, Amasino RM: FLOWERING LOCUS $\mathbf{C}$ encodes a novel MADS domain protein that acts as a repressor of flowering. Plant Cell 1999, 11:949-56.

36. Sheldon CC, Conn AB, Dennis ES, Peacock WJ: Different regulatory regions are required for the vernalization-induced repression of FLOWERING LOCUS $C$ and for the epigenetic maintenance of repression. Plant Cell 2002, 14:2527-2537.

37. Berry S, Hartley M, Olsson TSG, Dean C, Howard M: Local chromatin environment of a Polycomb target gene instructs its own epigenetic inheritance. Elife 2015, 4:e07205.

38. Wagner EJ, Carpenter PB: Understanding the language of Lys36 methylation at histone H3. Nat. Rev. Mol. Cell Biol. 2012, 13:115-126.

39. Morselli M, Pastor WA, Montanini B, Nee K, Ferrari R, Fu K, Bonora G, Rubbi L, Clark AT, Ottonello $S$, et al.: In vivo targeting of de novo DNA methylation by histone modifications in yeast and mouse. Elife 2015, 2015:1-21.

40. Sen P, Dang W, Donahue G, Dai J, Dorsey J, Cao X, Liu W, Cao K, Perry R, Lee JY, et al.: H3K36 methylation promotes longevity by enhancing transcriptional fidelity. Genes Dev. 2015, 29:1362-1376.

41. Wen H, Li Y, Xi Y, Jiang S, Stratton S, Peng D, Tanaka K, Ren Y, Xia Z, Wu J, et al.: ZMYND11 links histone H3.3K36me3 to transcription elongation and tumour suppression. Nature 2014, 508:263-268.

* $\quad$ This study identifies ZMYND11 as an H3.3-specific reader of H3K36me3 that regulates RNA Pol II elongation in suppression of tumorigenesis.

42. Li Y, Mukherjee I, Thum KE, Tanurdzic M, Katari MS, Obertello M, Edwards MB, McCombie WR, Martienssen R a, Coruzzi GM: The histone 
methyltransferase SDG8 mediates the epigenetic modification of light and carbon responsive genes in plants. Genome Biol 2015, 16:79.

* SDG8 is a H3K36me3 writer, especially for H3K36me3 spreading from 5' to 3 ' direction along the gene body, and is involved in the regulation of carbon and light response genes related to nutrient and energy metabolism.

43. Yang H, Howard M, Dean C: Antagonistic roles for H3K36me3 and H3K27me3 in the cold-induced epigenetic switch at Arabidopsis FLC. Curr. Biol. 2014, 24:1793-1797.

* $\quad$ Antagonism between H3K36me3 and H3K27me3 at the FLC locus in response to vernalization orchestrates the flowering transition.

44. Brien GL, Gambero G, O'Connell DJ, Jerman E, Turner SA, Egan CM, Dunne EJ, Jurgens MC, Wynne K, Piao L, et al.: Polycomb PHF19 binds H3K36me3 and recruits PRC2 and demethylase NO66 to embryonic stem cell genes during differentiation. Nat Struct Mol Biol 2012, 19:1273-1281.

45. Ng DWK, Wang T, Chandrasekharan MB, Aramayo R, Kertbundit S, Hall TC: Plant SET domain-containing proteins: Structure, function and regulation. Biochim. Biophys. Acta - Gene Struct. Expr. 2007, 1769:316329.

46. Shilatifard A: The COMPASS family of histone H3K4 methylases: mechanisms of regulation in development and disease pathogenesis. Annu. Rev. Biochem. 2012, 81:65-95.

47. Li Y, Han J, Zhang Y, Cao F, Liu Z, Li S, Wu J, Hu C, Wang Y, Shuai J, et al.: Structural basis for activity regulation of MLL family methyltransferases. Nature 2016, 530:447-452.

** Regulation/activation of MLL family histone methyltransferase (H3K4me writers) activity by shared complex components RBBP5-ASH2L.

48. Bertero A, Madrigal P, Galli A, Hubner NC, Moreno I, Burks D, Brown S, Pedersen RA, Gaffney D, Mendjan S, et al.: Activin/Nodal signaling and NANOG orchestrate human embryonic stem cell fate decisions by controlling the H3K4me3 chromatin mark. Genes Dev. 2015, 29:702717.

49. Berr A, McCallum EJ, Ménard R, Meyer D, Fuchs J, Dong A, Shen WH:

Arabidopsis SET DOMAIN GROUP2 is required for H3K4 trimethylation and is crucial for both sporophyte and gametophyte 
development. Plant Cell 2010, 22:3232-3248.

50. Tamada Y, Yun JY, Woo SC, Amasino RM: ARABIDOPSIS TRITHORAXRELATED7 is required for methylation of lysine 4 of histone $\mathrm{H} 3$ and for transcriptional activation of FLOWERING LOCUS C. Plant Cell 2009, 21:3257-3269.

51. Berr A, Shafiq S, Pinon V, Dong A, Shen WH: The trxG family histone methyltransferase SET DOMAIN GROUP 26 promotes flowering via a distinctive genetic pathway. Plant J. 2015, 81:316-328.

52. Cartagena JA, Matsunaga S, Seki M, Kurihara D, Yokoyama M, Shinozaki K, Fujimoto S, Azumi Y, Uchiyama S, Fukui K: The Arabidopsis SDG4 contributes to the regulation of pollen tube growth by methylation of histone H3 lysines 4 and 36 in mature pollen. Dev. Biol. 2008, 315:355368.

53. Saleh A, Alvarez-Venegas R, Yilmaz M, Le O, Hou G, Sadder M, AlAbdallat A, Xia Y, Lu G, Ladunga I, et al.: The highly similar Arabidopsis homologs of trithorax ATX1 and ATX2 encode proteins with divergent biochemical functions. Plant Cell 2008, 20:568-579.

54. Guo L, Yu Y, Law J a, Zhang X: SET DOMAIN GROUP2 is the major histone $\mathrm{H} 3$ lysine [corrected] 4 trimethyltransferase in Arabidopsis. Proc. Natl. Acad. Sci. U. S. A. 2010, 107:18557-18562.

55. Song ZT, Sun L, Lu SJ, Tian Y, Ding Y, Liu JX: Transcription factor interaction with COMPASS-like complex regulates histone H3K4 trimethylation for specific gene expression in plants. Proc. Natl. Acad. Sci. U. S. A. 2015, 112:2900-5.

* $\quad$ Sequence-specific transcription factors bZIP28 and bZIP60 interact with COMPASS-like components and likely recruit H3K4me3 writers to target genes in ER response.

56. Ferrari KJ, Scelfo A, Jammula S, Cuomo A, Barozzi I, Stützer A, Fischle W, Bonaldi T, Pasini D: Polycomb-Dependent H3K27me1 and H3K27me2 Regulate Active Transcription and Enhancer Fidelity. Mol. Cell 2014, 53:49-62.

57. Simon JA, Kingston RE: Occupying chromatin: Polycomb mechanisms for getting to genomic targets, stopping transcriptional traffic, and staying put. Mol Cell 2013, 49:808-824.

58. Justin N, Zhang Y, Tarricone C, Martin SR, Chen S, Underwood E, De 
Marco V, Haire LF, Walker PA, Reinberg D, et al.: Structural basis of oncogenic histone H3K27M inhibition of human polycomb repressive complex 2. Nat. Commun. 2016, 7:11316.

59. Brooun A, Gajiwala KS, Deng YL, Liu W, Bolaños B, Bingham P, He YA, Diehl W, Grable N, Kung PP, et al.: Polycomb repressive complex 2 structure with inhibitor reveals a mechanism of activation and drug resistance. Nat. Commun. 2016, 7:11384.

60. Peng JC, Valouev A, Liu N, Lin H: Piwi maintains germline stem cells and oogenesis in Drosophila through negative regulation of Polycomb group proteins. Nat. Genet. 2016, 48:1-11.

** In this study, the authors demonstrate a novel negative regulation model for PRC2 function: a Piwi protein physically interacts with PRC2 components and sequesters PRC2 to the nucleoplasm, thus reducing PRC2 binding to many targets and modulating transcription during oogenesis.

61. Blackledge NP, Rose NR, Klose RJ: Targeting Polycomb systems to regulate gene expression: modifications to a complex story. Nat. Rev. Mol. Cell Biol. 2015, 16:643-649.

62. Davidovich C, Wang X, Cifuentes-Rojas C, Goodrich KJ, Gooding AR, Lee JT, Cech TR: Toward a consensus on the binding specificity and promiscuity of PRC2 for RNA. Mol. Cell 2015, 57:552-559.

63. Wei C, Xiao R, Chen L, Cui H, Zhou Y, Xue Y, Hu J, Zhou B, Tsutsui T, Qiu $\mathrm{J}$, et al.: RBFox2 Binds Nascent RNA to Globally Regulate Polycomb Complex 2 Targeting in Mammalian Genomes. Mol. Cell 2016, doi:10.1016/j.molcel.2016.04.013.

64. Kaneko S, Son J, Shen SS, Reinberg D, Bonasio R: PRC2 binds active promoters and contacts nascent RNAs in embryonic stem cells. Nat Struct Mol Biol 2013, 20:1258-1264.

65. Lindroth AM, Shultis D, Jasencakova Z, Fuchs J, Johnson L, Schubert D, Patnaik D, Pradhan S, Goodrich J, Schubert I, et al.: Dual histone H3 methylation marks at lysines 9 and 27 required for interaction with CHROMOMETHYLASE3. EMBO J. 2004, 23:4286-4296.

66. Raynaud C, Sozzani R, Glab N, Domenichini S, Perennes C, Cella R, Kondorosi E, Bergounioux C: Two cell-cycle regulated SET-domain proteins interact with proliferating cell nuclear antigen (PCNA) in Arabidopsis. Plant J. 2006, 47:395-407. 
67. Jacob Y, Bergamin E, Donoghue MT a, Mongeon V, LeBlanc C, Voigt $\mathrm{P}$, Underwood CJ, Brunzelle JS, Michaels SD, Reinberg D, et al.: Selective methylation of histone $\mathrm{H} 3$ variant $\mathrm{H} 3.1$ regulates heterochromatin replication. Science 2014, 343:1249-53.

* Using crystallography, the authors show that ATXR5/6 specifically methylates lysine 27 of histone $H 3$ variant $H 3.1$ through a specific contact between SET domain and alanine 31 of H3.1. Threonine 31 of H3.3, by contrast, inhibits methyltransferase activity.

68. Iwasaki M, Paszkowski J: Epigenetic memory in plants. EMBO J. 2014, 33:1-12.

69. Blackledge NP, Farcas AM, Kondo T, King HW, McGouran JF, Hanssen LL, Ito S, Cooper S, Kondo K, Koseki Y, et al.: Variant PRC1 complexdependent $\mathrm{H} 2 \mathrm{~A}$ ubiquitylation drives PRC2 recruitment and polycomb domain formation. Cell 2014, 157:1445-1459.

70. Schwartz YB, Pirrotta V: Ruled by Ubiquitylation: A New Order for Polycomb Recruitment. Cell Rep. 2014, 8:321-325.

71. Yang C, Bratzel F, Hohmann N, Koch M, Turck F, Calonje M: VAL-and AtBMI1-Mediated H2Aub initiate the switch from embryonic to postgerminative growth in arabidopsis. Curr. Biol. 2013, 23:1324-1329.

72. Molitor AM, Bu Z, Yu Y, Shen WH: Arabidopsis AL PHD-PRC1 Complexes Promote Seed Germination through H3K4me3-toH3K27me3 Chromatin State Switch in Repression of Seed Developmental Genes. PLoS Genet. 2014, 10.

73. Lodha M, Marco CF, Timmermans MC: The ASYMMETRIC LEAVES complex maintains repression of KNOX homeobox genes via direct recruitment of Polycomb-repressive complex2. Genes Dev 2013, 27:596-601.

74. Xiao J, Jin R, Shen M, Wagner J, Yu X, He C, Santos AM, Helliwell C, Pruneda-Paz JL, Kay SA et al.: Cis- and trans-determinants of Polycomb Repressive Complex 2 recruitment in Arabidopsis. Science 2016 , in revision.

** In this study, the authors define functional PRES and PRE interacting transcription factors as well as PRE enriched cis motifs. The analyses converge on two classes of transcription factors (class 1 BPC and C1-2i $D$ $\mathrm{Zn}$ finger) and their cis motifs which are necessary and sufficient for direct recruitment of Polycomb Repressive Complex 2 (PRC2) in Arabidopsis and 
for Polycomb silencing.

75. Deng W, Buzas DM, Ying H, Robertson M, Taylor J, Peacock WJ, Dennis ES, Helliwell C: Arabidopsis Polycomb Repressive Complex 2 binding sites contain putative GAGA factor binding motifs within coding regions of genes. BMC Genomics 2013, 14:593.

76. Wang H, Liu C, Cheng J, Liu J, Zhang L, He C, Shen WH, Jin H, Xu L, Zhang Y: Arabidopsis Flower and Embryo Developmental Genes are Repressed in Seedlings by Different Combinations of Polycomb Group Proteins in Association with Distinct Sets of Cis-regulatory Elements. PLoS Genet. 2016, 12:1-25.

77. Zhou Y, Hartwig B, Velikkakam James G, Schneeberger K, Turck F: Complementary activities of TELOMERE REPEAT BINDING proteins and Polycomb Group complexes in transcriptional regulation of target genes. Plant Cell 2015, 28:TPC2015-00787-RA.

78. Hecker A, Brand LH, Peter S, Simoncello N, Kilian J, Harter K, Gaudin V, Wanke D: The Arabidopsis GAGA-Binding Factor BASIC PENTACYSTEINE6 Recruits the POLYCOMB-REPRESSIVE COMPLEX1 Component LIKE HETEROCHROMATIN PROTEIN1 to GAGA DNA Motifs. Plant Physiol 2015, 168:1013-1024.

79. Kassis JA, Brown JL: Polycomb group response elements in Drosophila and vertebrates. Adv Genet 2013, 81:83-118.

80. Olmo I Del, López JA, Vázquez J, Raynaud C, Piñeiro M, Jarillo JA: Arabidopsis DNA polymerase $\epsilon$ recruits components of Polycomb repressor complex to mediate epigenetic gene silencing. Nucleic Acids Res. 2016, doi:10.1093/nar/gkw156.

81. Xu M, Hu T, Smith MR, Poethig RS: Epigenetic Regulation of Vegetative Phase Change in Arabidopsis. Plant Cell 2016, 28:28-41.

82. Liu X, Gao L, Dinh TT, Shi T, Li D, Wang R, Guo L, Xiao L, Chen X: DNA Topoisomerase I Affects Polycomb Group Protein-Mediated Epigenetic Regulation and Plant Development by Altering Nucleosome Distribution in Arabidopsis. Plant Cell 2014, 26:28032817.

83. De Lucia F, Crevillen P, Jones AME, Greb T, Dean C: A PHD-polycomb repressive complex 2 triggers the epigenetic silencing of FLC during vernalization. Proc. Natl. Acad. Sci. U. S. A. 2008, 105:16831-16836. 
84. Sung S, Amasino RM: Vernalization in Arabidopsis thaliana is mediated by the PHD finger protein VIN3. Nature 2004, 427:159-164.

85. Qüesta JI, Song J, Geraldo N, An H, Dean C, Michaels SD, Amasino RM, Sheldon CC, Rouse DT, Finnegan EJ, et al.: Arabidopsis transcriptional repressor VAL1 triggers Polycomb silencing at FLC during vernalization. Science 2016, 353:485-8.

** The study by Qüesta and colleagues identified a conserved RY cis motif in the FLC locus at a region required for FLC silencing that is bound by PHDfinger protein VAL1. VAL1 physically interacts with PRC1 and with components of the ASAP complex including SAP18, and is required for efficient silencing of FLC by Polycomb Repressive Complex 2 (PRC2) during vernalization in Arabidopsis.

86. Liang SC, Hartwig B, Perera P, Mora-García S, de Leau E, Thornton H, de Alves FL, Rapsilber J, Yang S, James GV, et al.: Kicking against the PRCs - A Domesticated Transposase Antagonises Silencing Mediated by Polycomb Group Proteins and Is an Accessory Component of Polycomb Repressive Complex 2. PLoS Genet. 2015, 11:e1005660.

* A domesticated transposase (ALP1) antagonizes PCG silencing through competition with PRC2-interacting complex components.

87. Heo JB, Sung S: Vernalization-Mediated Epigenetic Silencing by a Long Intronic Noncoding RNA. Science 2011, 331:76-79.

88. Ariel F, Jegu T, Latrasse D, Romero-Barrios N, Christ A, Benhamed M, Crespi M: Noncoding transcription by alternative rna polymerases dynamically regulates an auxin-driven chromatin loop. Mol. Cell 2014, 55:383-396.

89. Xu L, Zhao Z, Dong A, Soubigou-Taconnat L, Renou JP, Steinmetz A, Shen WH: Di- and tri- but not monomethylation on histone H3 lysine 36 marks active transcription of genes involved in flowering time regulation and other processes in Arabidopsis thaliana. Mol. Cell. Biol. 2008, 28:1348-1360.

90. Berr A, Xu L, Gao J, Cognat V, Steinmetz A, Dong A, Shen WH: SET DOMAIN GROUP25 encodes a histone methyltransferase and is involved in FLOWERING LOCUS C activation and repression of flowering. Plant Physiol. 2009, 151:1476-1485.

91. Kumpf R, Thorstensen T, Rahman MA, Heyman J, Nenseth HZ, Lammens T, Herrmann U, Swarup R, Veiseth S V, Emberland G, et al.: The ASHR3 
SET-domain Protein Controls Cell Division Competence of the Meristem and Quiescent Centre of the Arabidopsis thaliana Primary Root. Plant Physiol. 2014, 166:632-643.

92. Sun C, Fang J, Zhao T, Xu B, Zhang F, Liu L, Tang J, Zhang G, Deng X, Chen $F$, et al.: The histone methyltransferase SDG724 mediates H3K36me2/3 deposition at MADS50 and RFT1 and promotes flowering in rice. Plant Cell 2012, 24:3235-3247.

93. Sui P, Jin J, Ye S, Mu C, Gao J, Feng H, Shen WH, Yu Y, Dong A: H3K36 methylation is critical for brassinosteroid-regulated plant growth and development in rice. Plant J. 2012, 70:340-347.

94. Hoppmann V, Thorstensen T, Kristiansen PE, Veiseth SV, Rahman MA, Finne K, Aalen RB, Aasland R: The CW domain, a new histone recognition module in chromatin proteins. EMBO J. 2011, 30:1939-52.

95. Shafiq S, Berr A, Shen WH: Combinatorial functions of diverse histone methylations in Arabidopsis thaliana flowering time regulation. New Phytol. 2014, 201:312-322.

96. Cazzonelli Cl, Nisar N, Roberts AC, Murray KD, Borevitz JO, Pogson BJ: A chromatin modifying enzyme, SDG8, is involved in morphological, gene expression, and epigenetic responses to mechanical stimulation. Front. Plant Sci. 2014, 5:533.

97. Sun B, Looi LS, Guo S, He Z, Gan ES, Huang J, Xu Y, Wee WY, Ito T: Timing mechanism dependent on cell division is invoked by Polycomb eviction in plant stem cells. Science 2014, 343:1248559.

98. Venkatesh S, Workman JL: Histone exchange, chromatin structure and the regulation of transcription. Nat. Rev. Mol. Cell Biol. 2015, 16:178189.

99. Chen X, Hu Y, Zhou DX: Epigenetic gene regulation by plant Jumonji group of histone demethylase. Biochim. Biophys. Acta - Gene Regul. Mech. 2011, 1809:421-426.

100. Torres IO, Kuchenbecker KM, Nnadi Cl, Fletterick RJ, Kelly MJS, Fujimori DG: Histone demethylase KDM5A is regulated by its reader domain through a positive-feedback mechanism. Nat. Commun. 2015, 6:6204.

** KDM5A, an H3K4me3 eraser, harbors a PHD1 reader domain that bind unmethylated $\mathrm{H} 3 \mathrm{~K} 4$. This enhances the catalytic activity of the eraser facilitating the spread of histone H3K4 demethylation on chromatin. 
101. Liu X, Secombe J: The Histone Demethylase KDM5 Activates Gene Expression by Recognizing Chromatin Context through Its PHD Reader Motif. Cell Rep. 2015, 13:2219-2231.

102. Chaturvedi CP, Somasundaram B, Singh K, Carpenedo RL, Stanford WL, Dilworth FJ, Brand M: Maintenance of gene silencing by the coordinate action of the H3K9 methyltransferase G9a/KMT1C and the H3K4 demethylase Jarid1a/KDM5A. Proc. Natl. Acad. Sci. U. S. A. 2012, 109:18845-50.

103. Jiang $D, G u X$, He Y: Establishment of the winter-annual growth habit via FRIGIDA-mediated histone methylation at FLOWERING LOCUS C in Arabidopsis. Plant Cell 2009, 21:1733-1746.

104. Liu F, Quesada V, Crevillén P, Bäurle I, Swiezewski S, Dean C: The Arabidopsis RNA-Binding Protein FCA Requires a Lysine-Specific Demethylase 1 Homolog to Downregulate FLC. Mol. Cell 2007, 28:398407.

105. Lu F, Cui X, Zhang S, Liu C, Cao X: JMJ14 is an H3K4 demethylase regulating flowering time in Arabidopsis. Cell Res. 2010, 20:387-390.

106. Yang H, Mo H, Fan D, Cao Y, Cui S, Ma L: Overexpression of a histone H3K4 demethylase, JMJ15, accelerates flowering time in Arabidopsis. Plant Cell Rep. 2012, 31:1297-1308.

107. Yang H, Han Z, Cao Y, Fan D, Li H, Mo H, Feng Y, Liu L, Wang Z, Yue Y, et al.: A companion cell-dominant and developmentally regulated H3K4 demethylase controls flowering time in Arabidopsis via the repression of FLC expression. PLoS Genet. 2012, 8.

108. Chen Q, Chen X, Wang Q, Zhang F, Lou Z, Zhang Q, Zhou DX: Structural Basis of a Histone H3 Lysine 4 Demethylase Required for Stem Elongation in Rice. PLoS Genet. 2013, 9.

109. Ning YQ, Ma ZY, Huang HW, Mo H, Zhao TT, Li L, Cai T, Chen S, Ma L, $\mathrm{He} \mathrm{XJ}$ : Two novel NAC transcription factors regulate gene expression and flowering time by associating with the histone demethylase JMJ14. Nucleic Acids Res. 2015, 43:1469-1484.

* Two NAC type transcription factors, NAC50 and NAC52, target JMJ14 to flowering time genes by binding to CTTGNNNNNCAAG consensus sequences.

110. Zhang S, Zhou B, Kang Y, Cui X, Liu A, Deleris A, Greenberg MV, Cui X, 
Qiu Q, Lu F, et al.: C-terminal domains of histone demethylase JMJ14 interact with a pair of NAC transcription factors to mediate specific chromatin association. Cell Discov. 2015, 1:15003.

* Two NAC type transcription factors, NAC50 and NAC52, target JMJ14 to flowering time genes by binding to CTTGNNNNNCAAG consensus sequences.

111. Bosselut R: Pleiotropic Functions of H3K27Me3 Demethylases in Immune Cell Differentiation. Trends Immunol. 2016, 37:102-13.

112. Manna S, Kim JK, Baugé C, Cam M, Zhao Y, Shetty J, Vacchio MS, Castro E, Tran B, Tessarollo L, et al.: Histone H3 Lysine 27 demethylases Jmjd3 and Utx are required for T-cell differentiation. Nat. Commun. 2015, 6:8152.

113. Lu F, Cui $X$, Zhang $S$, Jenuwein T, Cao X: Arabidopsis REF6 is a histone H3 lysine 27 demethylase. Nat. Genet. 2011, 43:715-719.

114. Noh B, Lee SH, Kim HJ, Yi G, Shin EA, Lee M, Jung KJ, Doyle MR, Amasino RM, Noh YS: Divergent roles of a pair of homologous jumonji/zinc-finger-class transcription factor proteins in the regulation of Arabidopsis flowering time. Plant Cell 2004, 16:2601-13.

115. Gan ES, Xu Y, Wong JY, Goh JG, Sun B, Wee WY, Huang J, Ito T: Jumonji demethylases moderate precocious flowering at elevated temperature via regulation of FLC in Arabidopsis. Nat. Commun. 2014, 5:5098.

* At elevated temperature, stabilized JMJ30 cooperates with JMJ32 to demethylate H3K27me3 at the FLC locus to prevent premature flowering.

116. Li T, Chen X, Zhong X, Zhao Y, Liu X, Zhou S, Cheng S, Zhou DX: Jumonji C domain protein JMJ705-mediated removal of histone H3 lysine 27 trimethylation is involved in defense-related gene activation in rice. Plant Cell 2013, 25:4725-36.

117. Cui X, Lu F, Qiu Q, Zhou B, Gu L, Zhang S, Kang Y, Cui X, Ma X, Yao Q, et al.: REF6 recognizes a specific DNA sequence to demethylate H3K27me3 and regulate organ boundary formation in Arabidopsis. Nat. Genet. 2016, doi:10.1038/pj.2016.37.

** Targeting of the H3K27me demethylase REF6 to its target loci is mediated through its $\mathrm{C}$-terminal $\mathrm{C} 2 \mathrm{H} 2$ zinc-finger domain which associates with a CTCTGYTY motif on the genomic DNA. 
118. Li C, Gu L, Gao L, Chen C, Wei CQ, Qiu Q, Chien CW, Wang S, Jiang L, Ai LF, et al.: Concerted genomic targeting of H3K27 demethylase REF6 and chromatin-remodeling ATPase BRM in Arabidopsis. Nat. Genet. 2016, doi:10.1038/pj.2016.37.

* $\quad$ REF6 binds to target loci through its $\mathrm{C} 2 \mathrm{H} 2$ zinc-finger domain to demethylate H3K27me3, and further counteracts PcG silencing by recruiting the chromatin remodeler BRM.

119. Hou X, Zhou J, Liu C, Liu L, Shen L, Yu H: Nuclear factor Y-mediated H3K27me3 demethylation of the SOC1 locus orchestrates flowering responses of Arabidopsis. Nat. Commun. 2014, 5:4601.

* Nuclear factor $Y(N F-Y)$ interacts with the PRE6 H3K27me3 demethylase and recruits it to the SOC1 promoter in control of flowering time.

120. Blackledge NP, Zhou JC, Tolstorukov MY, Farcas AM, Park PJ, Klose RJ: Cpg Islands Recruit a Histone H3 Lysine 36 Demethylase. Mol. Cell 2010, 38:179-190.

121. He J, Shen L, Wan M, Taranova O, Wu H, Zhang Y: Kdm2b maintains murine embryonic stem cell status by recruiting PRC1 complex to CpG islands of developmental genes. Nat. Cell Biol. 2013, 15:373-84.

122. Lu SX, Knowles SM, Webb CJ, Celaya RB, Cha C, Siu JP, Tobin EM: The Jumonji C domain-containing protein JMJ30 regulates period length in the Arabidopsis circadian clock. Plant Physiol. 2011, 155:906-15.

123. Yan Y, Shen L, Chen Y, Bao S, Thong Z, Yu H: A MYB-Domain Protein EFM Mediates Flowering Responses to Environmental Cues in Arabidopsis. Dev. Cell 2014, 30:437-448.

* The ambient temperature regulated MYC transcription factor EFM interacts with the JMJ30 histone demethylase and recruits it to the FT locus involved in circadian clock mediated flowering time regulation.

124. Yun M, Wu J, Workman JL, Li B: Readers of histone modifications. Cell Res. 2011, 21:564-78.

125. Chi $P$, Allis $C D$, Wang GG: Covalent histone modifications--miswritten, misinterpreted and mis-erased in human cancers. Nat. Rev. Cancer 2010, 10:457-69.

126. Chung HR, Xu C, Fuchs $A$, Mund A, Lange M, Staege $H$, Schubert $T$, Bian $\mathrm{C}$, Dunkel I, Eberharter A, et al.: PHF13 is a molecular reader and 
transcriptional co-regulator of H3K4me2/3. Elife 2016, 5:e10607.

* The PHD-domain protein PHF13, a reader of H3K4me, can interact with both Pol II and PRC2 and recruits them to active and bivalent promoters.

127. Lee WY, Lee D, Chung WI, Kwon CS: Arabidopsis ING and Alfin1-like protein families localize to the nucleus and bind to $\mathrm{H} 3 \mathrm{~K} 4 \mathrm{me} / 2$ via plant homeodomain fingers. Plant J 2009, 58:511-524.

128. Perrella G, Carr C, Asensi-Fabado MA, Donald NA, Páldi K, Hannah MA, Amtmann A: The Histone Deacetylase Complex (HDC) 1 protein of Arabidopsis thaliana has the capacity to interact with multiple proteins including histone 3-binding proteins and histone 1 variants. Plant Physiol. 2016, 171:pp.01760.2015.

* HDC1 interacts with AtING2, a reader of H3K4me3, suggesting a crosstalk between histone methylation and histone acetylation.

129. López-González L, Mouriz A, Narro-Diego L, Bustos R, Martínez-Zapater JM, Jarillo J a, Piñeiro M: Chromatin-Dependent Repression of the Arabidopsis Floral Integrator Genes Involves Plant Specific PHDContaining Proteins. Plant Cell 2014, 26:3922-38.

* The authors identify two PHD-domain containing proteins, EBS and SHL, that are able to recognize the $H 3 K 4 m e 2 / 3$ and interact with the histone deacetylase HDA6 to maintain a low level of $\mathrm{H} 3$ acetylation at the loci of the flowering time genes FT and SOC1.

130. Jiao L, Liu X: Structural basis of histone H3K27 trimethylation by an active polycomb repressive complex 2. Science 2015, 350:291.

131. Mohd-Sarip A, Venturini F, Chalkley GE, Verrijzer CP: Pleiohomeotic can link polycomb to DNA and mediate transcriptional repression. Mol. Cell. Biol. 2002, 22:7473-83.

132. Schoenfelder S, Sugar R, Dimond A, Javierre BM, Armstrong H, Mifsud B, Dimitrova E, Matheson L, Tavares-Cadete F, Furlan-Magaril M, et al.:

Polycomb repressive complex PRC1 spatially constrains the mouse embryonic stem cell genome. Nat. Genet. 2015, 47:1179-86.

133. Wani AH, Boettiger AN, Schorderet $P$, Ergun A, Münger $C$, Sadreyev RI, Zhuang $X$, Kingston RE, Francis NJ: Chromatin topology is coupled to Polycomb group protein subnuclear organization. Nat. Commun. 2016, 7:10291. 
134. Wang C, Liu C, Roqueiro D, Grimm D, Schwab R, Becker C, Lanz C, Weigel D: Genome-wide analysis of local chromatin packing in Arabidopsis thaliana. Genome Res. 2015, 25:246-256.

135. Katz A, Oliva M, Mosquna A, Hakim O, Ohad N: FIE and CURLY LEAF polycomb proteins interact in the regulation of homeobox gene expression during sporophyte development. Plant J. 2004, 37:707-719.

136. Zhang X, Clarenz O, Cokus S, Bernatavichute YV, Pellegrini M, Goodrich J, Jacobsen SE: Whole-genome analysis of histone $\mathrm{H} 3$ lysine 27 trimethylation in Arabidopsis. PLOS Biol. 2007, 5:1026-1035.

137. Turck F, Roudier F, Farrona S, Martin-Magniette ML, Guillaume E, Buisine N, Gagnot S, Martienssen RA, Coupland G, Colot V: Arabidopsis TFL2/LHP1 specifically associates with genes marked by trimethylation of histone H3 lysine 27. PLoS Genet. 2007, 3:0855-0866.

138. Jarillo JA, Piñeiro M: H2A.Z mediates different aspects of chromatin function and modulates flowering responses in Arabidopsis. Plant $\mathrm{J}$. 2015, 3:96-109.

139. Guo R, Zheng L, Park JW, Lv R, Chen H, Jiao F, Xu W, Mu S, Wen H, Qiu $\mathrm{J}$, et al.: BS69/ZMYND11 reads and connects histone H3.3 lysine 36 trimethylation-decorated chromatin to regulated pre-mRNA processing. Mol. Cell 2014, 56:298-310.

140. Bu Z, Yu Y, Li Z, Liu Y, Jiang W, Huang Y, Dong AW: Regulation of Arabidopsis Flowering by the Histone Mark Readers MRG1/2 via Interaction with CONSTANS to Modulate FT Expression. PLOS Genet. 2014, 10:1-11.

* MRG2 physical interacts with CONSTANS (CO) and binds to the FT locus and jointly activate it.

141. Xu Y, Gan ES, Zhou J, Wee WY, Zhang X, Ito T: Arabidopsis MRG domain proteins bridge two histone modifications to elevate expression of flowering genes. Nucleic Acids Res. 2014, 42:1096010974.

** MRG1 and MRG2, two MRG15 homologs in plants, recognize H3K36me3 and physically interact with the histone acetyltransferases HAM1 and HAM2 linking H3K36me3 with H4acetylation in regulating the expression of the flowering time genes FLC and FT.

142. Jin J, Shi J, Liu B, Liu Y, Huang Y, Yu Y, Dong A: MORF-RELATED 
GENE702, a Reader Protein of Trimethylated Histone H3 Lysine 4 and Histone H3 Lysine 36, Is Involved in Brassinosteroid-Regulated Growth and Flowering Time Control in Rice. Plant Physiol. 2015, 168:1275-1285. 